\title{
Open Virtual Worlds as Pedagogical Research Tools: Learning from the Schome Park Programme
}

\author{
Peter Twining $^{1}$ and Anna Peachey ${ }^{2}$ \\ ${ }^{1}$ The Centre for Research in Education \& Educational Technology (CREET), \\ The Open University, UK \\ P.Twining@open.ac.uk \\ ${ }^{2}$ The Open University, UK \\ A.Peachey@open.ac.uk
}

\begin{abstract}
This paper introduces the term Open Virtual Worlds and argues that they are 'unclaimed educational spaces', which provide a valuable tool for researching pedagogy. Having explored these claims the way in which Teen Second Life ${ }^{\circledR}$ virtual world was used for pedagogical experimentation in the initial phases of the Schome Park Programme is described. Four sets of pedagogical dimensions that emerged are presented and illustrated with examples from the Schome Park Programme.
\end{abstract}

Keywords: Research, Teen Second Life ${ }^{\circledR}$ virtual world, dimensions of practice, Schome, pedagogy.

\section{Introduction}

Virtual worlds provide simulated online environments where users, often called residents, interact through text or voice using two or three dimensional representations of themselves known as avatars. Many are driven by an imposed narrative that sets a goal or purpose to the environment, for example acquiring a set of skills or achieving a particular rank or increased social status. Some of these worlds enable content creation and avatar personalization within limits pre-defined by the environment's designers. For example, a user may be able to create a range of (predefined) swords; the user is in effect revealing existing swords rather them creating them. Open Virtual Worlds (OVRs) enable free activity alongside genuine content creation, scripting, and avatar personalization; the only limitations are based on the quality of the building and scripting tools provided and the users' ability to operate them. It is the multidimensional qualities of OVRs, such as Linden Lab's Second Life ${ }^{\circledR}$ virtual world (SL), which hold the most significant potential for rich, immersive teaching and learning activities, providing semi-authentic contexts for simulation, role play and experiential learning.

Whilst there is significant information to be drawn from a wider context of teaching and learning online and/or with virtual reality, our knowledge and understanding of teaching and learning in OVRs is very much in its infancy. For example the Open University (UK), as an 'early adopter' [1], has only been teaching in Second Life since 2006. 
Castronova [2] compared virtual worlds with the Wild West, claiming they provided new frontiers for people to explore. Gee [3] talked about the principles and patterns that are deemed to be appropriate in different social systems, which he called the 'design grammar' of the social system. He argued that virtual worlds entail new and different design grammars, which users have to learn or indeed co-create through their interactions. Twining [4] similarly claimed that OVRs represent 'unclaimed educational spaces'. This chapter will briefly explore the basis for that claim before going on to suggest that this makes OVRs powerful tools for researching pedagogy. The chapter will illustrate the ways in which OVRs have been used to support pedagogical experimentation within the Schome Park Programme (SPP), leading to the development of a set of dimensions of practice, some of which will be described.

\section{Open Virtual Worlds, 'Unclaimed Educational Spaces' and Pedagogical Exploration}

There are a number of features of OVRs that underpin our lack of understanding of their design grammars:

- The chance to explore that which would be difficult, expensive, dangerous or impossible to do in the physical world - both literally and pragmatically. Pragmatically it would be more difficult and expensive to set up a new learning community in the physical world than in a virtual world. Literally, there are things you can do in virtual worlds that are not possible in the physical world, such as flying like a bird or breathing without assistance underwater.

- The meaning of space is different because the constraints of the environment are different. Buildings are not needed to keep you warm and dry or to hold up pictures/displays, and you can travel huge virtual distances in an instant, so proximity is different to the definition in the physical world.

- The opportunity to work together with the minimum of contextual hierarchy. The influences of physical aspects of appearance such as gender, age, dress, etc. are significant in physical world educational settings. From this perspective, 'equality' over the age range in the SPP, and in virtual worlds in general, is easily achieved as interaction is mediated through avatars. Thomas [5] has observed that it is actually not the case that all avatars are 'equal' even in appearance; for example the degree to which each person has customised their avatar may be indicative of differences in power in relation to expertise, economic resource, etc. Nevertheless, the physical characterisation of the avatars does allow them to escape from the usually fixed differentials of physical world educational interactions [6].

- The lack of established social norms in OVRs means that actors have space to experiment. For example, during early contacts in Schome Park students would fly in and out of chat range apparently at random and/or would edit their appearance (sometimes quite drastically) during conversations. Socialisation defines the process by which individuals develop the habits, ideas, values and attitudes through which they learn to inhabit their culture or community: '... it prepares the individual for the roles he is to play, providing him with the necessary repertoire of habits, beliefs, and values, the appropriate patterns of emotional response and the 
modes of perception, the requisite skills and knowledge ...' [7]. The lack of established culture in virtual worlds requires users to establish the design grammars for their communities allowing for new models of socialisation.

The majority of children in the industrialised world start school by the age of around 5 years old. Their experience of primary, secondary and often tertiary education is overwhelmingly one of learning in a classroom with walls, floor, ceiling, tables and chairs, a black or whiteboard and a teacher. It is difficult therefore to conceive of a radically new model of education when we are each loaded with the social context and conceptual grammar of our own experience within existing education systems, where school is the dominant model. Engeström et al [8] submitted that it is 'very difficult for school communities to collectively analyse and redesign their practice'. From a situated socio-cultural perspective, where knowledge cannot be separated from the activity and situation in which it is produced, we accept that learning is the product of negotiation rather than 'individual construction' [9]. One solution to this burden of partiality would be to provide the opportunity for a radically different 'lived experience' of an alternative education system - precisely the opportunity for pedagogical experimentation afforded by the 'unknownness' of OVRs. Whilst people may have prejudices grounded in the media portrayal of virtual worlds, self-evaluation of their own computing skills, and expectations of computer 'games', most actors have little or no bias about definitions of education in OVRs.

The many education and training islands in Second Life adult and teen grids range from photorealistic reproductions of the physical world, where avatars use lecture theatres, sitting in rows to view slides delivered on virtual presentation screens, to fantastical spaces that stretch the metaphors beyond the known and familiar, challenging students to step free of any physical world contexts. See Figure 1 for illustration. Arguments are made for both as valid learning contexts with high potential for innovation, from challenging learners within their comfort zone to creating a truly unique perspective. It is precisely the lack of rules and accepted wisdom about working in this environment that holds significant appeal for anyone wishing to explore models of pedagogy.

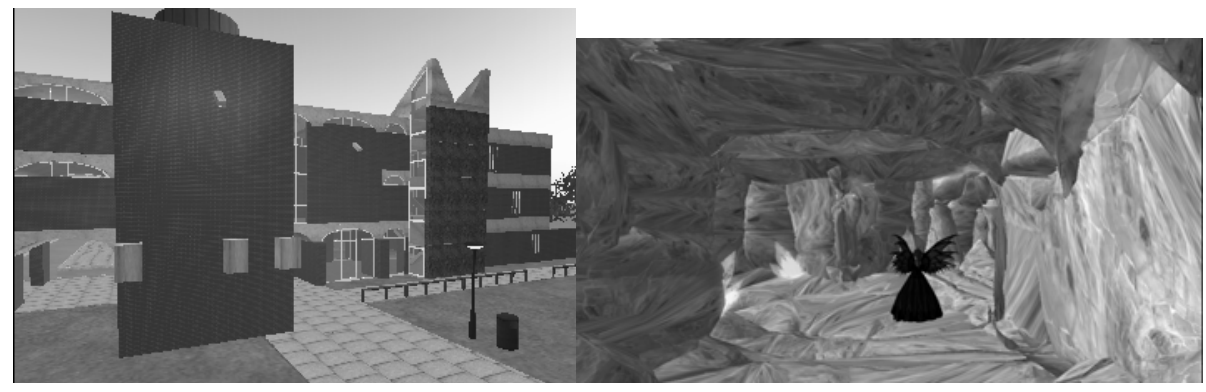

Fig. 1. Details from Sussex University Campus Island and Schome Park Beta The Sussex inworld campus comprises replica real life buildings complete with security cameras (Sussex also has an island where students are creating their own content with very few restrictions). In contrast Schome Park Beta includes rivers of lava and an underground crystal cavern. 
Table 1. Summary of key aspects of the first three phases of the SPP

\begin{tabular}{|c|c|c|c|c|}
\hline Aspect & $\begin{array}{l}\text { Phase } 1 \\
\text { (March to April 07) }\end{array}$ & $\begin{array}{l}\text { Phase } 2 \\
\text { (June to Dec 07) }\end{array}$ & \begin{tabular}{|l|} 
Phase 3a \\
(Jan to Mar 08)
\end{tabular} & $\begin{array}{l}\text { Phase 3b } \\
\text { (Apr to May 08) }\end{array}$ \\
\hline 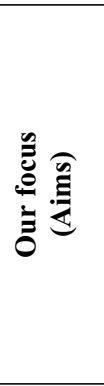 & $\begin{array}{l}\text { To explore the } \\
\text { educational potential } \\
\text { of virtual worlds } \\
\text { (with a particular } \\
\text { focus on developing } \\
\text { Second Life skills } \\
\text { and 'Knowledge Age } \\
\text { Skills'). To build a } \\
\text { community of } \\
\text { learners. }\end{array}$ & $\begin{array}{l}\text { To enhance } \\
\text { 'Knowledge Age } \\
\text { Skills'. To increase } \\
\text { student control and } \\
\text { responsibility for the } \\
\text { environment, the } \\
\text { curriculum and } \\
\text { support. To widen } \\
\text { the community (not } \\
\text { just gifted and } \\
\text { talented). }\end{array}$ & \multicolumn{2}{|c|}{$\begin{array}{l}\text { To enhance 'Knowledge Age } \\
\text { Skills'. To balance control and } \\
\text { responsibility for the environment, } \\
\text { the curriculum and support. To } \\
\text { widen the community and increase } \\
\text { its size. To explore the co- } \\
\text { existence of the Schome ethos with } \\
\text { school culture. }\end{array}$} \\
\hline \multirow[t]{2}{*}{ 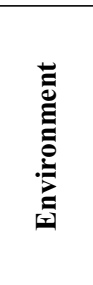 } & $\begin{array}{l}\text { Island divided into } \\
\text { six areas: Physics; } \\
\text { Ethics \& philosophy; } \\
\text { Archaeology; Scho- } \\
\text { op (generic support); } \\
\text { Shared meeting } \\
\text { areas; Sandbox. }\end{array}$ & $\begin{array}{l}\text { Island as naturalistic } \\
\text { and attractive } \\
\text { environment with } \\
\text { some core generic } \\
\text { areas - student } \\
\text { control of } \\
\text { planning/building. }\end{array}$ & $\begin{array}{l}\text { Two islands: } \\
\text { One student } \\
\text { controlled }+ \text { one } \\
\text { staff controlled. } \\
\text { Immersive game } \\
\text { theme for new } \\
\text { island. }\end{array}$ & $\begin{array}{l}\text { Two islands. } \\
\text { Project teams } \\
\text { allocated plots } \\
\text { of land with } \\
\text { full controls } \\
\text { (e.g. } \\
\text { terraforming) }\end{array}$ \\
\hline & \multicolumn{4}{|c|}{ Island, wiki and forum available $24 / 7 / 365$} \\
\hline \multirow[t]{2}{*}{$\frac{n}{\grave{c}}$} & \multirow{2}{*}{$\begin{array}{l}149 \text { students aged } 13 \\
\text { to } 17 \text { from National } \\
\text { Association of Gifted } \\
\text { and Talented Youth } \\
\text { (NAGTY). Staff } \\
\text { from four universities } \\
\text { and the National } \\
\text { Physical Laboratory; } \\
\text { PhD students; } \\
\text { Consultants. }\end{array}$} & $\begin{array}{l}\text { Ongoing students } \\
\text { from Phase } 1 \\
\text { New } 13 \text { to } 17 \text { year } \\
\text { old students from } \\
\text { range of sources } \\
\text { (inc. USA). }\end{array}$ & \multicolumn{2}{|c|}{$\begin{array}{l}\text { Ongoing students from Phase } 2 \\
\text { New } 13 \text { to } 17 \text { year old students } \\
\text { from range of sources, including: } \\
\text { South East Grid for Learning } \\
\text { (broadband consortium), 'School } \\
\text { groups' from UK and USA. }\end{array}$} \\
\hline & & \multicolumn{3}{|c|}{$\begin{array}{c}\text { Staff from two universities; PhD students; Consultants; } \\
\text { Teachers; Parents }\end{array}$} \\
\hline$\stackrel{\Xi}{\Xi}$ & $\begin{array}{l}\text { Three strands of } \\
\text { formal activity } \\
\text { (Physics, Ethics and } \\
\text { Philosophy, } \\
\text { Archaeology) + } \\
\text { discrete 'taught } \\
\text { sessions' (e.g. } \\
\text { research methods) + } \\
\text { student led activity }\end{array}$ & $\begin{array}{l}\text { Student led activity } \\
\text { (inc continuation of } \\
\text { formal strands from } \\
\text { Phase 1) + } \\
\text { Machinima creation } \\
\text { + discrete 'staff led' } \\
\text { sessions (e.g. } \\
\text { Sudoku) }\end{array}$ & $\begin{array}{l}\text { Student led } \\
\text { activity (inc } \\
\text { continuation of } \\
\text { Phase } 2 \text { strands } \\
\text { and new strands } \\
\text { such as Time } \\
\text { Travelers) + new } \\
\text { strands led by } \\
\text { staff (e.g. } \\
\text { Maths) }\end{array}$ & $\begin{array}{l}\text { Major focus on } \\
\text { projects (led by } \\
\text { students and/or } \\
\text { staff) }\end{array}$ \\
\hline \multirow[t]{2}{*}{$\frac{1}{2}$} & $\begin{array}{l}\text { Staff scheduled } \\
\text { sessions for each } \\
\text { formal curriculum } \\
\text { area }\end{array}$ & $\begin{array}{l}\text { Staff available to } \\
\text { provide support in } \\
\text { Schome Park }\end{array}$ & $\begin{array}{l}\text { Greater staff } \\
\text { support for } \\
\text { strands of } \\
\text { activity (e.g. } \\
\text { Maths) and for } \\
\text { student led } \\
\text { activity }\end{array}$ & $\begin{array}{l}\text { Staff support } \\
\text { focused on } \\
\text { projects }\end{array}$ \\
\hline & \multicolumn{4}{|c|}{$\begin{array}{c}\text { Peer - peer support; Information in wiki; Discussion in forum; Emergency help } \\
\text { button to summon staff }\end{array}$} \\
\hline
\end{tabular}




\section{Pedagogical Experimentation in the Schome Park Programme}

The Schome Park Programme (SPP) set out to explore the potential of virtual worlds, considering their capacity to act as spaces in which visions of future practices and pedagogies can be built and experienced, making it "possible to construct, investigate and interrogate hypothetical worlds" [10]. In late 2006 the SPP chose Teen Second Life ${ }^{\circledR}$ virtual world (TSL), in conjunction with a wiki and forum, to give participants in the programme a 'lived experience' of radically different approaches to education. The first three phases of the SPP are summarised in Table 1 (overleaf). For more detailed information and reports about the Schome Park Programme see http://www. schome.ac.uk/

Analysis of the activities that the students and staff engaged in between March 07 and May 08 led to the development of a number of dimensions of practice which highlight key pedagogical issues relevant to any learning context, four sets of which are explored here.

\section{Emerging Dimensions of Practice}

\subsection{Playfulness}

We have already suggested that one of the most powerful and intriguing features of OVRs is that they encourage experimentation and rule testing. Warburton [11] suggested that there was a tension between playfulness and professionalism and that this inhibited innovation in virtual worlds. This could be seen as being reflected in the variation in the extent to which participants within the SPP experimented with building over the three Phases of the SPP, which is summarized in Table 2.

Table 2. Summary of building activity across the phases

\begin{tabular}{|l|l|l|l|}
\hline & Amount of building & Rules about building & Overall \\
\hline Phase 1 & $\begin{array}{l}\text { A vast amount - most } \\
\text { students involved to } \\
\text { some degree }\end{array}$ & $\begin{array}{l}\text { Students could build } \\
\text { anywhere above 250 } \\
\text { metres (and in the } \\
\text { sandbox) }\end{array}$ & $\begin{array}{l}\text { Very few rules. Focus } \\
\text { on the process of } \\
\text { learning how to build. }\end{array}$ \\
\hline Phase 2 & $\begin{array}{l}\text { Much more limited } \\
\text { both in terms of number } \\
\text { of builds and numbers } \\
\text { of students involved in } \\
\text { building. }\end{array}$ & $\begin{array}{l}\text { All builds required } \\
\text { planning permission (via } \\
\text { the forum). }\end{array}$ & $\begin{array}{l}\text { Larger sandbox created. } \\
\text { Builds outside the } \\
\text { sandbox required } \\
\text { imposed) regulations } \\
\text { and red tape around } \\
\text { building. Increased } \\
\text { focus on the quality of } \\
\text { the buildings. }\end{array}$ \\
\hline Phase 3b & $\begin{array}{l}\text { An increase in building } \\
\text { involving more students } \\
\text { (though still not as } \\
\text { much as in Phase 1) }\end{array}$ & $\begin{array}{l}\text { Sandbox increased in } \\
\text { size. } \\
\text { Plots of land allocated to } \\
\text { projects (with full } \\
\text { controls such as } \\
\text { terraforming). }\end{array}$ & $\begin{array}{l}\text { Reduction in rules and } \\
\text { red tape (compared } \\
\text { with Phases 2 and 3a). } \\
\text { Focus on developing } \\
\text { builds to support } \\
\text { projects. }\end{array}$ \\
\hline
\end{tabular}


The introduction of planning regulations, which could be seen as a greater professionalization of the community, meant that students had to plan their builds and persuade other people to support their applications before they could commence building (except in the sandbox). This was not only a slow process that required the use of the forum, but it also placed an emphasis on the building itself. Thus there was a shift away from the process of building towards the quality and appropriateness of the final product. The differences suggested two dimensions that impact on the degree of experimentation in building: regulation and product-process focus. These are shown in Figure 2, and it is suggested that they impact on the overall level of experimentation or playfulness.

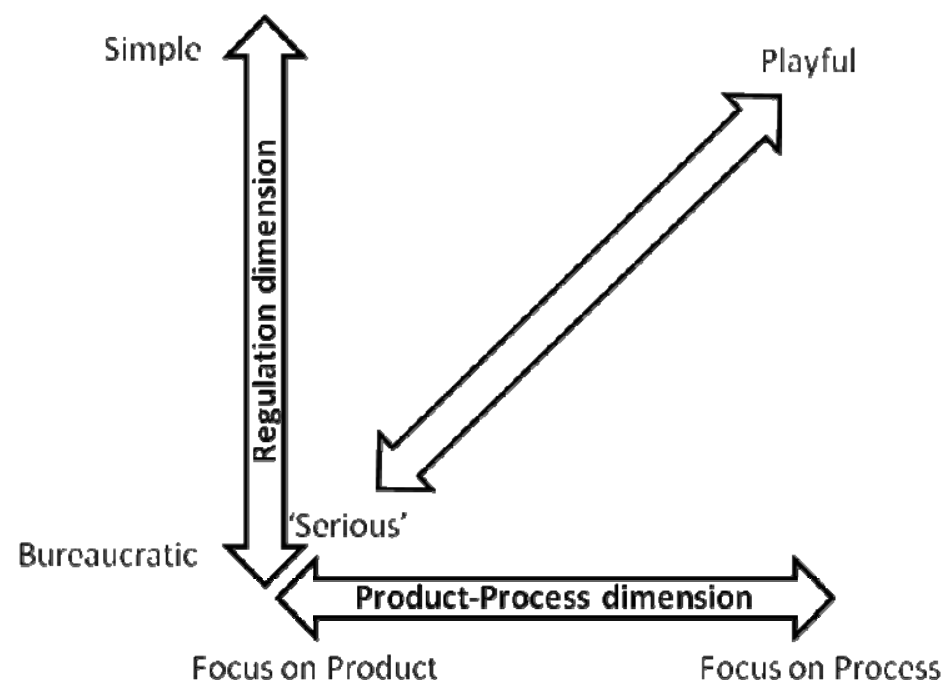

Fig. 2. Dimensions of playfulness

These dimensions may help to explain why OVRs encourage pedagogical exploration: initially people do not understand the 'design grammar' for the virtual space and are thus unconstrained by norms/rules of the community. They start to experiment and learn to operate in the environment, which inevitably involves a focus on what they can do (i.e. process). As people become more established in a virtual community rules become established, as they did in Schome Park, and the focus shifts from what is possible to the quality of production, thus restricting the degree of experimentation that is acceptable.

\subsection{Pedagogy}

Within Schome Park the nature of the activities varied along what we have called the pedagogy dimension, which is illustrated in Figure 3. Within the SPP students engaged in an archaeology session which involved researching topics on the web (learning about) and they then created artifacts in-world (learning by doing). At other times students organised in-world weddings and the trial of an avatar accused of 
murdering another avatar (learning through role play). Learning by becoming was evidenced by the Schome Park regattas, where students actually were sailors and race officers, and by the governance group where students took on the responsibility of planning officers for the community, creating rules and subsequently enforcing them.

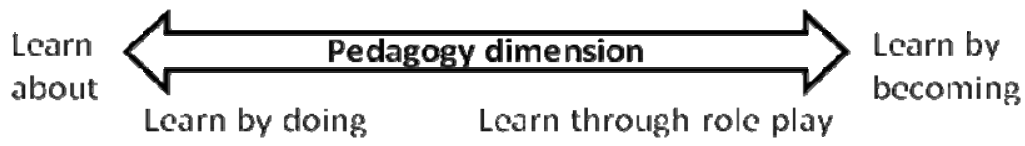

Fig. 3. The Pedagogy Dimension

\subsection{Theoretical Stance}

The predominant theories of learning/development underpinning formal education (at least in the industrialised world) are based on the premise that learning is an epistemological problem involving individual psychological processes that lead to the acquisition of knowledge [12]. Thus, an individual constructivist view sees learners as active agents who construct knowledge, in the form of their own internal model of 'the world', as the result of interactions within it. This perspective sees knowledge as being a commodity that an individual can acquire. The pedagogical focus therefore is on the individual, and assessment concentrates on what an individual knows, which will be reflected in the things that an individual can do (without support).

The Schome Park Programme is underpinned by a sociocultural view of learning, in which knowledge is seen as a social practice rather than a commodity. Hence knowledge moves from being something you acquire to being an ability to act within a community of practice. Thus there was a focus within Schome Park on each individual's participation and ability to act within the community. Figure 4 illustrates these differences in perspective.

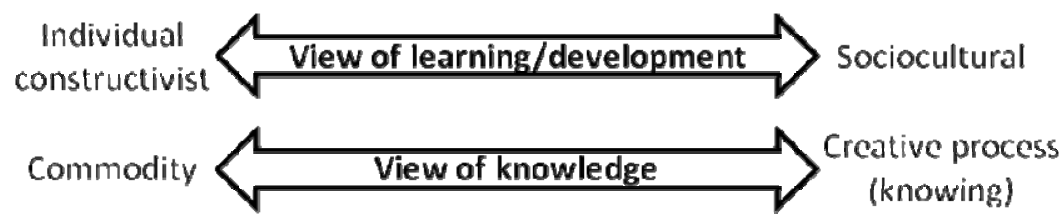

Fig. 4. Theoretical stance

The tension between a traditional school theoretical stance and the Schome Park stance was highlighted very clearly just after a group of students and their teacher joined Phase 3 of the Programme. The teacher had set the children some homework, which was to find the answers to some questions about the Schome Park Programme. Her intention was that the students would search for information in the wiki and explore Schome Park itself in order to find the answers to these questions. One of her students (SchomerE), having first tried to find the answers for himself, posted a message in the forum asking if anyone knew the answers to 23 of the questions. This almost immediately provoked a challenge from one of his classmates who seemed to be questioning the validity of this approach to doing the homework. Within 3.5 
minutes of the original message a reply had been posted by an established student member of the community (SchomerG) providing the answers to 20 of the questions. Twelve minutes later another experienced student posted a message that provided answers to the remaining three questions and corrected a couple of the answers that had been provided by SchomerG. A couple of hours later an established member of staff posted a message congratulating SchomerE on taking advantage of the knowledge of the community:

Lateral thinking - SchomerE is going to do well in Schome 9

Now that the community has collaborated on SchomerE's homework - has anyone else got any we can help with?

SParker4 16-Jan-08 @19.49

A discussion ensued about whether or not SchomerE had cheated. There was a clear divide in perspective between the new students and the existing ones. The class teacher, who was in the difficult position of being constrained by her school context whilst also trying to fit in with the Schome Park ethos, diplomatically explained that she felt that SchomerE had undermined what she had intended he would learn from the homework. SchomerE subsequently reported that "it doesn't look like I'm in TOO much trouble" (Forum 18-Jan-08). Underpinning this episode was a difference in theoretical stance, with most of the new students (and teacher) adopting a traditional (individual constructivist) perspective and the established members of Schome Park adopting a sociocultural one.

\subsection{Curriculum Dimensions}

A vast range of different activities took place on Schome Park, some of which seemed to be more effective (as vehicles to support learning) than others. The nature of the activities differed in many ways, but two dimensions which seemed to be particularly relevant when thinking about the educational potential of activities related to who specified what the activity would be (in effect who defined the curriculum) and how much choice students had about taking part in the activities or not (curriculum choice). Figure 5 shows how 'Traditional school' and a number of the Schome Park activities map onto these two inter-related dimensions. The shaded area illustrates the region that our experiences in Schome Park seem to suggest provide the most productive contexts for learning.

Traditional school (which was not a feature of the SPP) typically gives learners no choice about whether or not to participate because they are required to go to school (i.e. is imposed), and it has an externally defined curriculum (i.e. not defined by the learner).

Chosen projects relates to work that a group of students from a school who were working in Schome Park engaged in. The students were given a choice about whether they wished to take part in the SPP or some other activity; they had to choose from the available options, hence their curriculum choice was imposed choice. Having decided to engage with the SPP the students were taken through some taught sessions (not shown in the figure) which included the homework mentioned in the previous section. They were then allowed to choose a partner and come up with any project that they wished to pursue within Schome Park. Thus at this stage they were able to freely negotiate the content of the curriculum. 


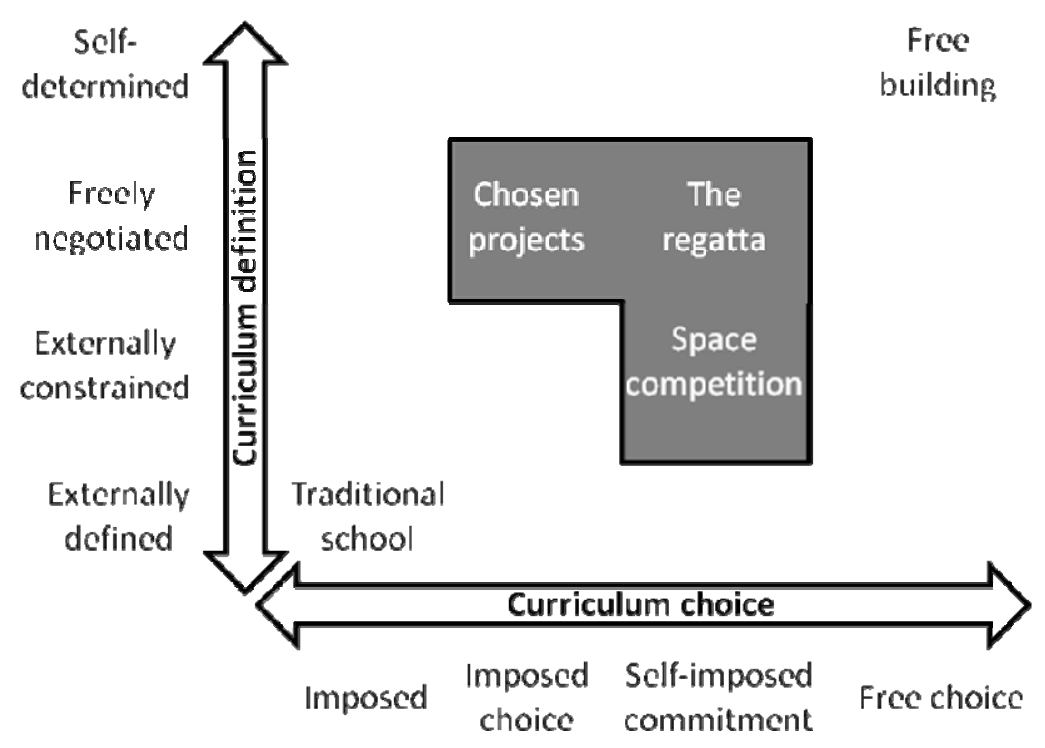

Fig. 5. Curriculum Dimensions

The regatta involved students in all aspects of preparing for and running a series of boat races around Schome Park. The students came up with the initial idea for the activity, but having decided to do it and advertised it to the community, they had imposed a commitment on themselves to see the activity through (self-imposed commitment). What the activity involved was also something that the students were free to decide, but they did have to agree amongst themselves what was going to happen (and indeed who was going to do which things). This was free negotiation (on the curriculum content dimension) in that it was negotiation between peers.

A member of staff suggested to the students that they enter the space competition, which involved designing an experiment that could be carried out from a satellite orbiting in space. The prize was to have your experiment actually implemented. The students had free choice about whether to take part in the competition (though not everyone who wanted to was able to in the end), but having signed up to take part they were committed to seeing through the whole project, which lasted several months (self-imposed commitment). The curriculum was externally constrained, in as much as the rules of the competition and judging criteria set limits on what your entry to the competition needed to focus on. However, within those constraints the students had a great deal of freedom to design any experiment that they wished.

Free building is used here to describe the sort of unconstrained building activity that took place in Phase 1 of the SPP, when students were allowed to build anywhere they wished above $250 \mathrm{~m}$. The students had total choice about whether to build or not (free choice on the Curriculum choice dimension) and about what to build and whether to add scripts to enhance their builds (self-determined on the Curriculum definition dimension). 


\section{Conclusions}

The Schome Park Programme used the power of OVRs, as unclaimed spaces that encourage pedagogical exploration, to explore dimensions of practice in order to inform our thinking about schome (the optimal education system for the learning age). The dimensions of practice that emerged from this early work on the SPP help to distinguish between key aspects of practice within Schome Park, and would appear to have relevance across any educational context. However, there is a long way to go before we have a clear understanding of what schome (the optimal education system for the learning age) should be like. It also remains to be seen whether or not OVRs will retain their strength as pedagogical playgrounds, and if they do, then what impact (if any) will practices emerging within virtual worlds have on practice in the physical world?

\section{References}

1. Rogers, E.M.: Diffusion of Innovations. Free Press of Glencoe, Macmillan Company (1962)

2. Castronova, E.: Exodus to the Virtual World. Palgrave Macmillan, New York (2007)

3. Gee, J.P.: What video games have to teach us about learning and literacy. Palgrave Macmillan, New York (2003)

4. Twining, P.: Education Systems for the Future? JISC RSC Journeys into Virtual Worlds conference (February 2008),

http: / / kn. open.ac.uk/public/document. cfm?docid=11030

5. Thomas, A.: Youth online: identity and literacy in the digital age. Peter Lang (2007)

6. Peachey, A., Gillen, J., Ferguson, R.: Fluid leadership in a multi-user virtual environment educational project with teenagers: Schome Park. In: International Society for Cultural and Activity Research conference: Ecologies of Diversities - the developmental and historical interarticulation of human meditational forms, September 8-13 (2008)

7. Chinoy, E.: Society: An Introduction to Sociology. Random House, New York (1961)

8. Engeström, Y., Engeström, R., Suntio, A.: Can a school community learn to master its own future? An activity-theoretical study of expansive learning among middle school teachers. In: Wells, G., Claxton, G. (eds.) Learning for life in the $21^{\text {st }}$ Century, pp. 211-224. Blackwell, Oxford (2002)

9. Murphy, P.: Defining Pedagogy. In: Hall, K., Murphy, P., Soler, J. (eds.) Pedagogy and Practice: Culture and Identities, pp. 28-39. Sage, London (2008)

10. Squire, K.: From content to context: Videogames as designed experience. Educational Researcher 35(8), 19-29 (2006)

11. Warburton, S.: Controlling Second Life: six barriers to innovation in MUVE-based learning and teaching. In: LYICT Conference, Kuala Lumpur, July 7-12 (2008), http: //warburton. typepad.com/liquidlearning/2008/07/ six-barriers-to.html

12. Lave, J.: Everyday Life and Learning. In: Murphy, P., McCormick, R. (eds.) Knowledge and Practice: Representations and Identities, pp. 3-14. Sage, London (2008) 